\title{
〔第10回放射線技術シンポジゥム]
}

\section{0. 拡大ステレオシステムの諸問題}

\author{
九州大学医学部附属病院放射線部 \\ 東 丸廣 女・安河内恭輔・馬 場 仁 \\ 新 開 英 秀・森 山有 相
}

Key Words: Magnified stereoscopic radiography, Focal MTF, Vibration, Noise, System

\section{PROBLEMS ON THE MAGNIFIED STEREOSCOPIC' SYSTEM \\ HiRohumi Higashimaru, Kyosuke YasukohCH, Hitoshi BABA, EISYUH SHINKAI and YUHSUKE MORIYAMA}

\section{Summary}

Focal MTF and resolution on the pendulm shift of the X-ray focal system was evaluated and measured as regards vibration and noise on a 17,000 round per minit (rpm) tube and compared with those on the $10,000 \mathrm{rpm}$ one. Also, the refomation of collimation and the AOT system, etc. are describead.

\section{1.はじめに}

近年，各社より様々な拡大ステレオシステムが開発さ れている. 当院のシステムでは，拡大ステレオバイプレ ーン撮影機構をはじめ,コンタクトステレオ, I.I. 間接 撮影等多くの機能を備え，また， $0.2 \mathrm{~mm}$ 焦点で $12 \mathrm{~kW}$ の出力を出せるなど多くの長所をるつ反面，下記の通り 幾つ汃の問題点もある.

(1) 振子移動による焦点のレスポンスの低下

(2) 高速回転による振動，騒音の影響

(3) 機構および構造上の問題点

(4) 設計思想による相違点

(5) 理論的なむの (焦点間距離)

こ机らのうち，(1)，(2)を中心に検討した.

\section{2. 装置構成}

○高電圧発生装置, 制御装置: シーメンス, パンドロ ス,オプチマチック
○ X線管装置：シーメンス OPT1 110/12/50HSG

○フィルムチェシジャ: AOT-S

\section{3. 方法, 結果および考察}

\section{1 $0.2 \mathrm{~mm}$ 焦点の MTF}

$0.2 \mathrm{~mm}$ 焦点の MTF をスリット法により求めた。 ス リットは $0.05 \mathrm{mmPb}$ 厚, $0.05 \mathrm{~mm}$ 幅のものを用い, 2 倍拡大で撮影した。撮影条件は $77 \mathrm{kV}, 64 \mathrm{mAs}$ 亿て Scan する時のaperture は $100 \mu \mathrm{m} \times 1000 \mu \mathrm{m}$ ，サンプリング間隔 は $5 \mu \mathrm{m}$ とした. 測定位置については下記の 5 点とし た. (1)X線照射野中心 (Center), (2)陰極側 (Cathode)。 (3)陽極側 (Anode), (4)焦点移動方向 (Left とする), (5) (4)の反対位置 (Right とする) 以上(2)〜(5)については, フィルム上で Center より $15 \mathrm{~cm}$ 離れた点を測定点とし た.Fig. 1 は焦点をLeft 側に12.5 mm移動した時の fa方 向 (X線管軸々平行方向) の変化である. 破線注焦点を移 動させない時，すなわちX線管の中心にある時の MTF である、破線と実線の差があまり認められないととから， 


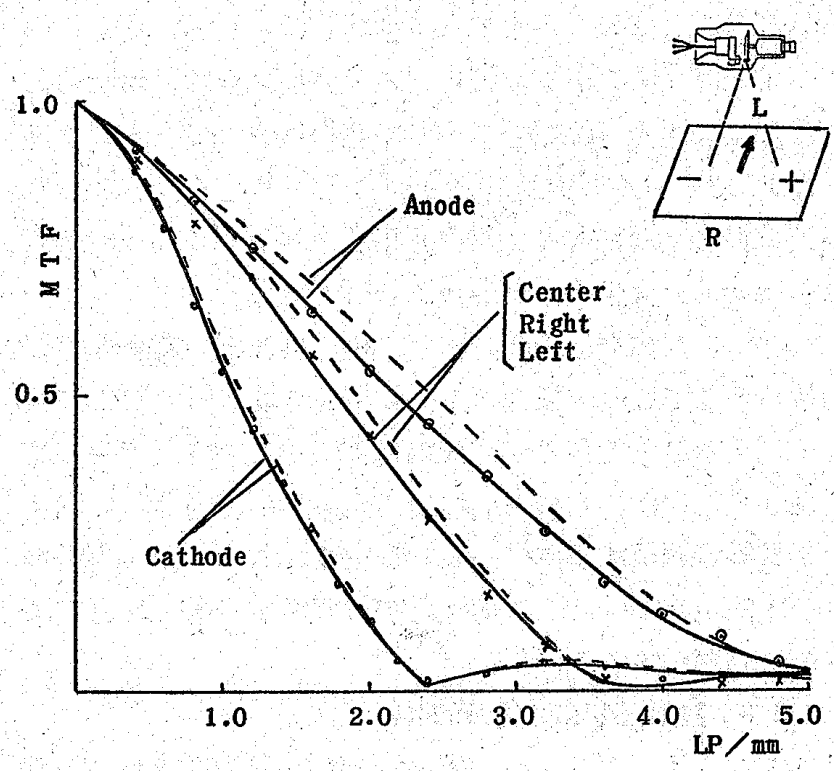

Fig. 1. MTF on $0.2 \mathrm{~mm}$ focal $(f a)$. The differences of focal shift to left.

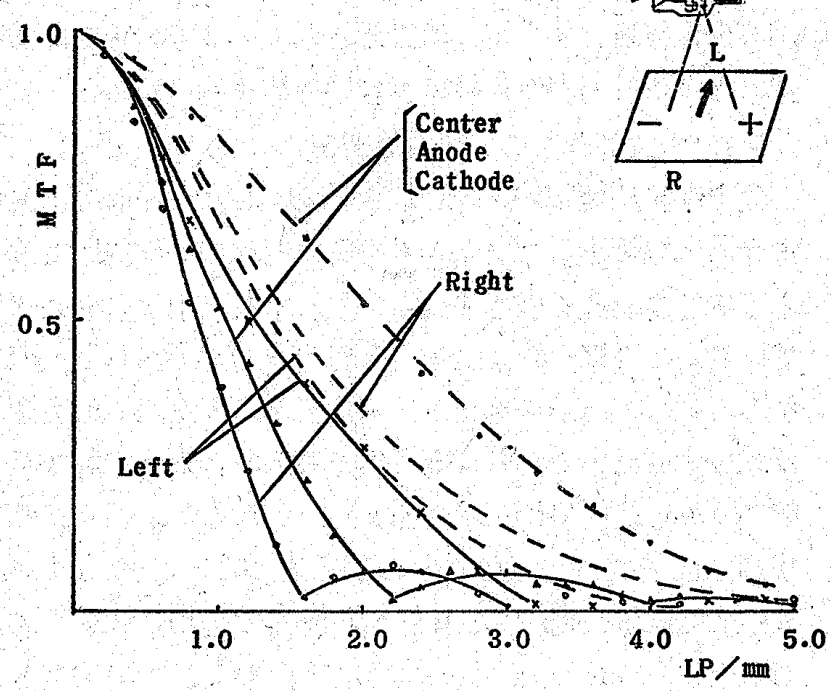

Fig. 2. MTF on $0.2 \mathrm{~mm}$ focal $(f b)$. The differences of focal shift to left.

振子移動による $f a$ 方向の MTF の低下は少ないととが

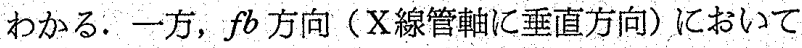
はその差は影著であり，焦点を振ることによって MTF は大きく影響を受ける (Fig. 2)。すなわち, 焦点を左に 振ると左側の MTFはあまり変化せず，右側ほど低下 する.とれは焦点を左へ振るしとによって左右方向の歪 みが大きくなったためと考えられる。

\section{2 チャートによる総合解像度}

$0.2 \mathrm{~mm}$ 焦点でX線テストチャート (Kyokko Typ 2 Nr. $26145 \quad 1.0 \sim 4.86 \mathrm{LP} / \mathrm{mm}$ 厚 $\mathrm{d}=0.05 \mathrm{mmPb}$, 公 比1. 11 , Typ $1 \mathrm{Nr} .225460 .5 \sim 10 \mathrm{LP} / \mathrm{mm}$ 厚さ d $=0.05$

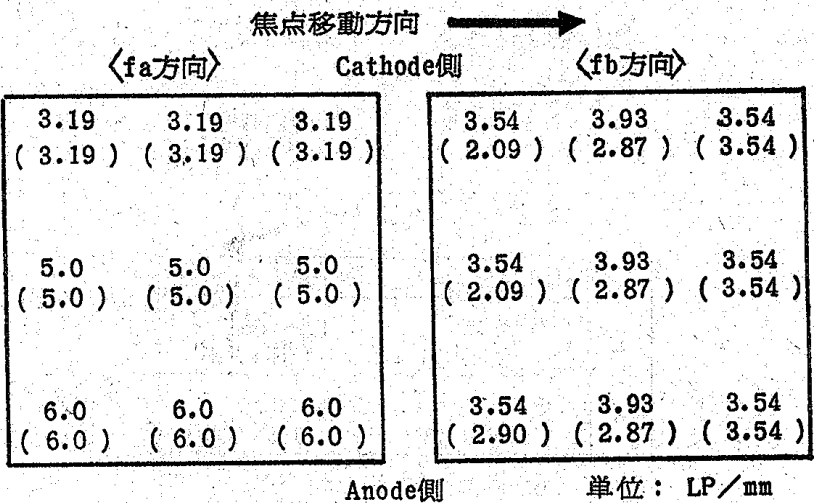

Fig. 3. The compare of resolution by the chart ( 2 times magnified).

(): the resolution of focal shifted.

$\mathrm{mmPb}$ )を2 倍拡太で撮影. フィルム Fuji RXO, 増感 紙 Fuji G-4，grid $\ominus$ 。 結果を Fig. 3 亿示した. 上段の 值は焦点が中心位置にあるとき，下段の（）は焦点を振 った時である. 焦点を振ることによる影響は fa 方向で は認められないが，fb方向ではかなり大きい。例えば 焦点を左に振ったとすると右端の $\mathrm{fb}$ 方向の解像度は極 端に恵くなり，その差は公比1.11のチャートで 5 段階に もおよぶ，一方，陰極側と陽極側とでは焦点移動に関係 なく fa方向でかなりの差が認められる。乙れは陽極の target 角度が $10^{\circ}$ であるてとが影響していると考えられ る.

\section{3 高速回転による振動の影響}

振動計はリオンVM-20A を使用. 振動のピックアッ プはマグネットを用い,最大変位量を求めた。X線管は 3 倍回転および 6 倍回転について測定し 比較した（Table 1). 両者の差はわずかであり，6倍回転による画質の低 下はないものと考える、以前使用していた拡大用 X線管 装置 (Siemens Bi 125/3/50，3 倍回転) の振動は $8 \mu \mathrm{m}$ 程度であったしとを考えると，相対的に最大変位量は小 さくなっており，乙れは現在の保持装置 (Siemens 社製 3DM) の固有振動に対する対策が明確になっていたため と考えられる。

\section{4 高速回転による騒音の影響}

Table 1. Compare of deviation of vibrations.

\begin{tabular}{r|r|r|r}
\hline & & \multicolumn{2}{|c|}{ peak to peak } \\
$\mathrm{X}$ 線 管装置 & 陽極回転数 & \multicolumn{2}{|c|}{ Max. $\mu \mathrm{m}$} \\
\hline OPTI $110 / 12 / 50 \mathrm{HSG}$ & 17,000 r.p.m & $\mathrm{a}$ & $\mathrm{b}$ \\
\hline OPTI $150 / 40 / 72 \mathrm{C}$ & 10,000 r.p.m & 1.5 & 1.9 \\
\hline
\end{tabular}

a : parallel to longitude.

$\mathrm{b}$ : vertical to longitude. 


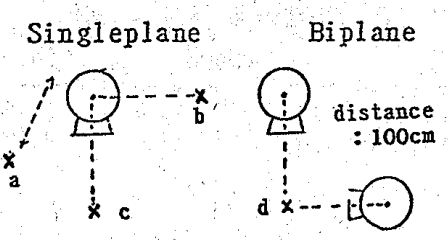

\begin{tabular}{|c|c|c|}
\cline { 2 - 4 } & 1000 r.p.m & 17000 r.p.m \\
\hline$a$ & $\begin{array}{c}60 \sim 61 \\
(65 \sim 68)\end{array}$ & $\begin{array}{c}65 \sim 68 \\
(68 \sim 70)\end{array}$ \\
\hline$b$ & $\begin{array}{c}59 \sim 62 \\
(65 \sim 68)\end{array}$ & $\begin{array}{c}70 \sim 72 \\
(70 \sim 72)\end{array}$ \\
\hline$c$ & $\begin{array}{c}62 \sim 64 \\
(65 \sim 67)\end{array}$ & $\begin{array}{c}68 \sim 71 \\
(68 \sim 71)\end{array}$ \\
\hline$d$ & & $\begin{array}{c}75 \sim 76 \\
(75 \sim 76)\end{array}$ \\
\hline
\end{tabular}

単位 : ホン

Fig. 4. Noise from X-ray tube. (): C Mode.

踽音計はりオン NA-09を使用。測定は $\mathrm{A}, \mathrm{C}$ の 2 特 性で行った（Fig. 4).6倍回転では 3 倍回転に比べて 5〜10ホン程度高くなっている。 また, Biplane 撮影時 には75ホン以上となり患者にとっては不安を増長させる 大きな一因になっていると思われる。

一方，A特性とC 特性の差は 6 倍回転でほとんどない が，乙れは高調波成分が多いこしによる.

\section{5. 機構および構造上の問題点}

Fig. 5 A, B は Collimation 機構を図示したものであ るが,コリメータの先端に取り付けられた遮蔽板がX線 管焦点の移動に同期して連動的に動き，余分なX線を力 ットするようになっている。しかし、フィルム上の照射 野を基集に遮蔽するため，Cに示す黒い部分（ステレオ 視できない部分）のカットができない。とれはステレオ 用コリメータの現製品全般について言えるでとであるが， ステレオ視できる被写体範囲を基準に考え，Cに示す黒
い部分のX線カットができる機構が望まれる。また，D に示すようにステレオ視できる範囲を大きくするために は, フィルムの位置をずらして連続撮影ができるような AOT 亿対する機構的な改善が必要亡考える. との高速 連続撮影装置の改善は焦点間距離を現在の $2.5 \mathrm{~cm}$ から 3〜 $4 \mathrm{~cm}$ と大きくした場合にも有效である.

さらに, 構造上の問題しして焦点外X線の遮蔽法が挙 げられる。乙れる拡大ステレオ用X線管装置全般につい て言えることであるが，X線管軸に刘して垂直方向の遮 蔽が難しいか，本装置の場合，焦点移動に同期して焦点 外X線を遮蔽する機構の設置が望まれる。また，本装置 で大焦点 $(0.6 \mathrm{~mm})$ 亿切換え密着撮影する場合などには 特に問題があると考える。

\section{6 設計思想による問題点}

本システムでは, $\mathrm{kV}$ 調整器, $\mathrm{mAs}$ 調整器共 $\operatorname{tap}$ 式に なっているが, 1 tap 切換えるととにより濃度が最高 0.5 〜 0,6 程度変化する場合むあり，濃度の微調整が困難な 場合が少なくない(Fig. 6). との調整器は 1 tap で出力 が $25 \%$ 程度変化するように設計されているとの事である が，もう少し出力変化幅の少ない機構を望みたい.

\section{7 理論的なもの (焦点間距離) について}

焦点移動距離 $25 \mathrm{~mm}$ は土井理論 ${ }^{1}$ 亿基つくあのであ るが，実際撮影したフィルムを 2 枚並べて立体視してみ

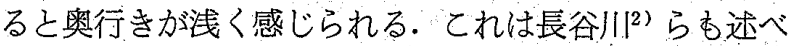
ているように視空間にあっては奥行きに差のある2点間 をみる時，正面から見た 2 点間が広がる程その奥行き感 は減少するためである.今，焦点間距離 $2.5 \mathrm{~cm}$, 撮影距 離 $100 \mathrm{~cm}$ で拡大率 2 㥉, 瞳の左右距離 $6.0 \mathrm{~cm}$, 観察距 離 $60 \mathrm{~cm}$ とすると，被写体の奥行き $10 \mathrm{~cm}$ のもは何 cm Kステレオ視されるが土井理論に基つく式より求 めると $11.1 \mathrm{~cm}$ となる．すなわち，計算上はコンタクト
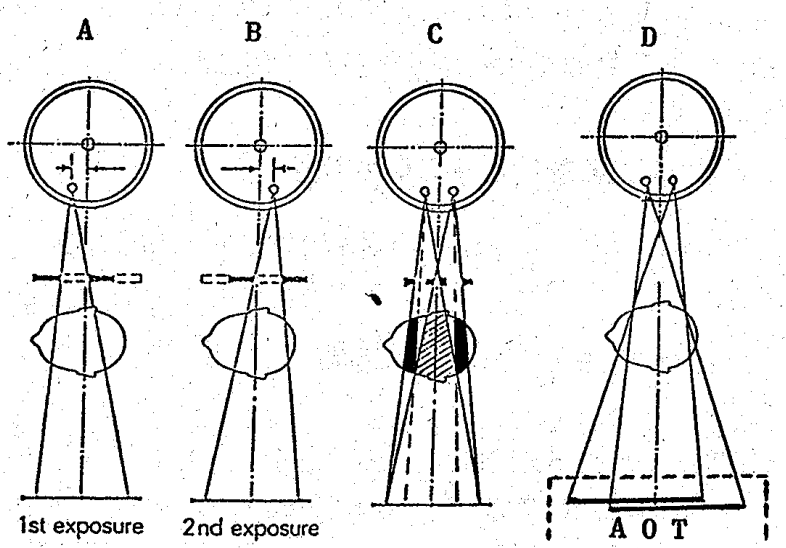

Fig. 5. Refomation of collimation and AOT system.
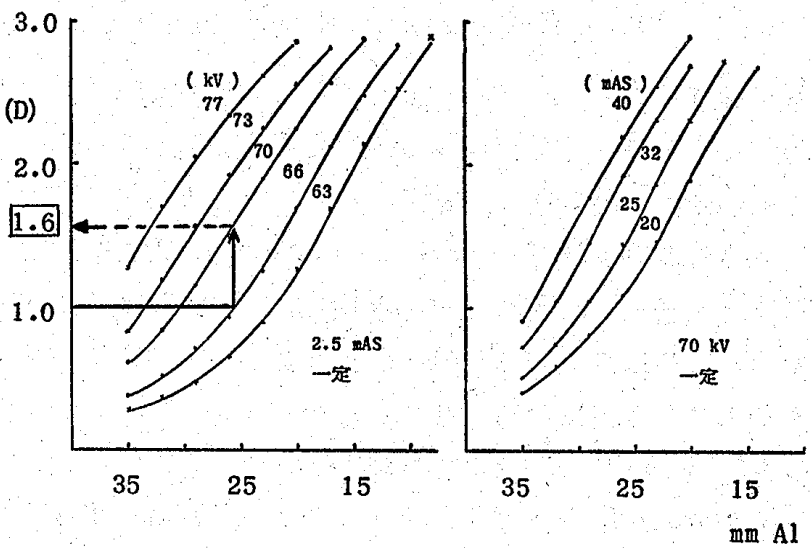

Fig. 6. Density differences changing $\mathrm{kV}$ and $\mathrm{mAs}$ regurator. 
ステレオ撮影の場合とほぼ同一の奥行きとなるのである が，実際の写真では正面から見た 2 点間は 2 倍拡大され て広がっているため, 視空間における奥行き感は減少す るのである.では至適焦点間距離は何 $\mathrm{cm}$ かというとと になるが, 高橋了ららが報告しているように $4 \mathrm{~cm}$ 程度と 考える。ただし，2焦点間距離を大きくするとステレオ 視できる範囲が狭くなるので，3.5で述べたように何ら かの機構的改善加望まれる。

\section{4. 結語}

われわれが使用している拡大ステレオンステムの諸問 題について述ベたが，本質的な問題ししては，焦点移動 によるX線管軸に対する垂直方向の極端なレスポンスの 低下とステレオ效果の不足があげられる。また、コリメ ータ，高速連続撮影装置（AOTなど）の一貫したシス テムの改良・開発が大きな課題である。騒音については，
JIS では機械装置の騒音は 65 ホとなっており, 改善は 必須と思 $う . \mathrm{kV}, \mathrm{mAs}$ 調整器についてはメーカの思想に よるあのであり難しい問題と思われるが，日本における 装置に対する代様感覚にマッチした機能・性能の開発を 切に望みたい.

稿を終えるに当り，御指導，御協力を頂いた諸先輩に 感謝けたします。

\section{文 献}

1) Doi, K., Rossmann, K. and Eugene, E. Duda: A new method of cerebral angiography. Radiology, 124, 394-401, (1977).

2）長谷川正浩, 清水 浩：X線拡大立体撮影について. 日本医放会誌，42(5)，429-434，(1982).

3) 高橋胿正: 神経放射線診断の新しい方向. 日本医放 会誌, 42(2), 203-222, (1982). 